EDUKIDS: Jurnal Pertumbuhan, Perkembangan, dan Pendidikan Anak Usia Dini

Jln. Dr. Setiabudhi No. 229 Kota Bandung 40154. e-mail: edukid @upi.edu

website: http://ejournal.upi.edu/index.php/edukid

\title{
PROFIL KOMPETENSI PROFESIONAL GURU TAMAN KANAK-KANAK DITINJAU DARI KUALIFIKASI AKADEMIK
}

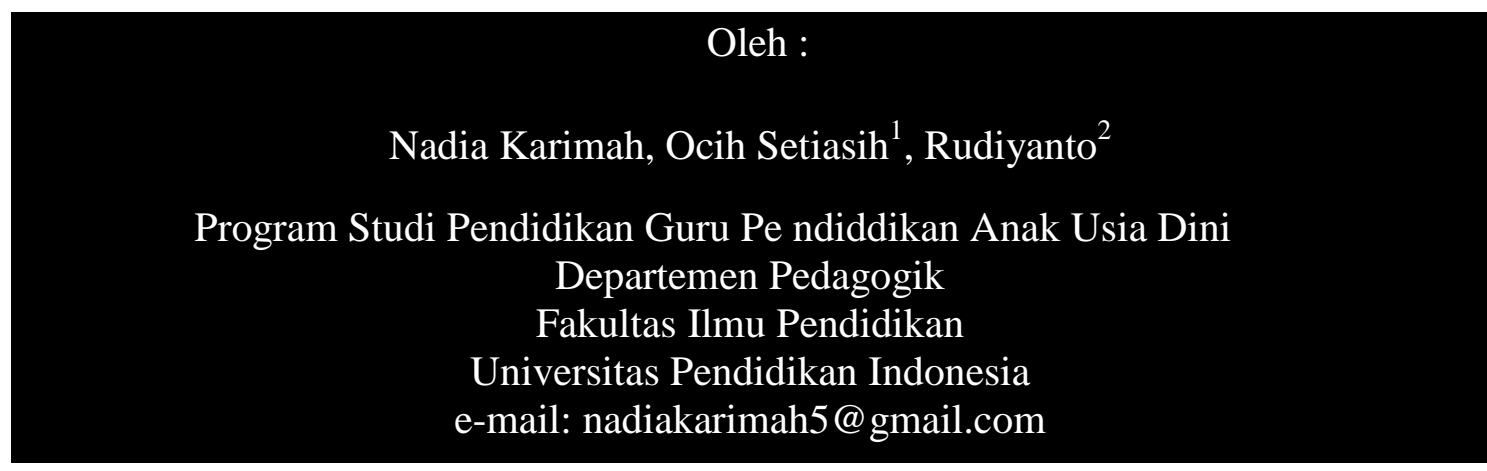

\begin{abstract}
Abstrak: Penelitian ini bertujuan untuk mengetahui perbedaan profil kompetensi profesional guru TK ditinjau dari kualifikasi akademik dengan kategori guru yang memiliki ijazah terakhir S1 yang relevan dengan bidang PAUD dan S1 yang tidak relevan dengan bidang PAUD. Metode yang digunakan dalam penelitian ini adalah metode penelitian ex post facto. Populasi pada penelitian ini adalah seluruh guru TK di Kecamatan Cibinong Kabupaten Bogor yang terdiri dari 38 guru S1 yang relevan dengan bidang PAUD dan 37 guru S1 yang tidak relevan dengan bidang PAUD. Instrumen dalam penelitian ini mengacu pada Permendikbud No. 137 Tahun 2014 yang kemudian dikembangkan oleh peneliti. Analisis statistik yang digunakan untuk mengetahui perbedaan profil kompetensi profesional pada penelitian ini menggunakan uji Independent Sample T-test. Hasil penelitian ini terdiri dari 1) Profil kompetensi profesional guru S1 yang relevan dengan bidang PAUD berada pada kategori tinggi $84,97 \%$, sedangkan pada guru S1 yang tidak relevan dengan bidang PAUD berada pada kategori tinggi 72,97 \%. 2) Profil kualifikasi akademik guru TK di Kecamatan Cibinong Kabupaten Bogor yaitu terdapat 50,67 \% guru yang memiliki ijazah terakhir S1 yang relevan dengan bidang PAUD dan 49,33\% guru yang memiliki ijazah terakhir S1 yang tidak relevan dengan bidang PAUD. 3) Terdapat perbedaan yang signifikan $(\mathrm{p}=0,021<0,05)$ antara guru $\mathrm{S} 1$ yang relevan dan tidak relevan dengan PAUD. Berdasarkan hasil penelitian ini, peneliti memberikan rekomendasi kepada guru TK agar memenuhi standar kualifikasi akademik guna meningkatkan kompetensi profesional.
\end{abstract}

\section{Kata Kunci : Guru TK, Kompetensi Profesional, Kualifikasi Akademik}

\footnotetext{
${ }^{\mathrm{T}}$ Penulis Penanggungjawab

${ }^{2}$ Penulis Penanggungjawab
} 


\section{PENDAHULUAN}

Pendidikan anak usia dini memiliki karakteristik yang berbeda dengan pendidikan lainnya, karena anak usia dini memiliki ciri tersendiri dalam perkembangan dan cara belajar nya, sehingga memerlukan bimbingan yang sesuai agar anak dapat berkembang secara optimal. Menurut Setiasih (2008, hlm. 1) keberhasilan program pendidikan dipengaruhi oleh dua faktor yaitu faktor internal dan faktor eksternal. Faktor eksternal di antaranya karakteristik masyarakat, kondisi ekonomi, sistem politik, dan tatanan kehidupan lainnya; sedangkan faktor internal di antaranya kurikulum, sarana dan prasarana, faktor peserta didik, dan faktor pendidik.

Guru memiliki peran yang sangat penting dalam dunia pendidikan, karena guru lah yang menyampaikan programprogram yang ada dalam kurikulum sekolah kepada anak secara langsung. Apabila sebuah lembaga PAUD memiliki program yang sangat baik, fasilitas yang memadai, tetapi tidak dibarengi dengan guru yang memahami cara merealisasikan program lembaga PAUD dan mampu memanfaatkan fasilitas lembaga PAUD dengan baik, maka kemampuan akan sulit untuk berkembang. Kompetensi guru yang kurang baik akan menjadikan anak gagal dalam melanjutkan pendidikan ke jenjang yang lebih tinggi.

Undang-undang Republik Indonesia Nomor 14 Tahun 2005 tentang Guru dan Dosen Bab I Pasal I ayat I menyatakan bahwa : Guru adalah pendidik profesional dengan tugas utama mendidik, mengajar, membimbing, mengarahkan, melatih, menilai, dan mengevaluasi peserta didik pada penilaian anak usia dini jalur pendidikan formal, pendidikan dasar, dan pendidikan menengah.

Pengetahuan mengenai profesi keguruan sangat membantu guru untuk mampu memiliki dan menguasai empat kompetensi yang tercantum dalam UU No. 14 Tahun 2005 tentang Guru dan Dosen pasal 1 ayat 1 , yakni kompetensi pedagogik, kompetensi kepribadian, kompetensi sosial, dan kompetensi profesional. Profesionalisme guru PAUD dapat dipengaruhi oleh kompetensi yang dimiliki guru.

Guru yang memiliki kompetensi profesional adalah guru yang mampu melaksanakan tugasnya sebagai seorang pendidik. Guru yang profesional juga harus mampu melakukan perencanaan, melaksanakan pembelajaran, mengevaluasi hasil pembelajaran, mengembangkan sistem pembelajaran, dan melakukan tindakan reflektif terhadap kinerja nya. Guru yang profesional harus mampu membentuk konsep dan struktur materi yang akan diajarkan kepada anak, mampu menghubungkan materi ajar dengan kehidupan sehari-hari, dan mampu mengevaluasi perkembangan anak selama belajar. Janice Beaty dalam Setiasih (2008, hlm. 9) mengemukakan bahwa tenaga pendidik anak usia dini yang profesional memiliki komitmen terhadap profesinya, berperilaku etis, memiliki dasar pengetahuan dalam bidangnya, memperoleh beberapa bentuk pelatihan, telah memberikan berbagai bentuk layanan pendidikan anak usia dini. Di samping ciri-ciri tersebut, guru juga harus memperhatikan standar kualifikasi akademik sesuai dengan Peraturan Menteri Pendidikan dan Kebudayaan Republik Indonesia Nomor 137 Tahun 
2014 tentang Standar Nasional Pendidikan Anak Usia Dini BAB VII Pasal 25 Ayat 1 yang menyatakan bahwa:

Kualifikasi akademik Guru PAUD:

a. Memiliki ijazah Diploma empat (D-IV) atau Sarjana (S1) dalam bidang pendidikan anak usia dini, dan kependidikan lain yang relevan dengan sistem pendidikan anak usia dini, atau psikologi yang diperoleh dari program studi terakreditasi, dan

b. Memiliki sertifikat Pendidikan Profesi Guru (PPG) PAUD dari perguruan tinggi yang terakreditasi.

Menjadi seorang guru yang kompeten harus didukung dengan pengalaman kerja yang cukup, karena dengan adanya pengalaman kerja maka akan belajar lebih banyak hal-hal baru. Menurut peneliti dari Leeds University, Evans, (2008), profesionalitas itu sudah menjadi sebuah ideologi, sikap, tindakan, intelektualitas, dan secara epistimologis berbasis pada pendirian individu saat harus melaksanakan tugastugas profesionalnya.

Danim, (2010) menegaskan bahwa tuntutan kehadiran guru yang profesional tidak pernah surut, karena dalam latar belakang proses kemanusiaan dan pemanusiaan, ia hadir sebagai subjek yang paling diandalkan. Seorang guru yang profesional setidaknya harus menguasai dua karakteristik utama dalam mengajar, yakni bahan ajar dan peserta didik. Penguasaan kedua elemen tersebut sangat dibutuhkan untuk menentukan metode dan strategi pembelajaran.
Faktor-faktor yang dapat mempengaruhi kompetensi profesional guru antara lain iklim organisasi atau lingkungan kerja guru, sikap yang dimiliki guru, pengalaman kerja, dan juga pendidikan terakhir guru. Pendidikan terakhir guru dapat menjadi acuan bagaimana cara seorang guru mengajar. Hal ini sejalan dengan pendapat Sugiyono (dalam Pudyastuti, 2010, hlm. 3) bahwa kemampuan guru dapat dipengaruhi oleh beberapa faktor seperti potensi dasar dalam diri, latar belakang pendidikan, pendidikan ataupun pelatihan, dan pengalaman belajar. Terlepas dari seorang guru akan terus belajar seiring dengan berjalannya waktu, faktor pendidikan terakhir juga menjadi salah satu acuan untuk menilai seberapa profesionalnya seorang guru tersebut karena guru yang telah mengemban pendidikan S1 yang relevan dengan bidang PAUD mempelajari ilmu-ilmu dasar pendidikan anak usia dini, sedangkan yang tidak mengembang pendidikan S1 yang relevan dengan bidang PAUD tidak mempelajarinya dalam jenjang pendidikan formal. Guru yang memiliki ijazah terakhir S1 yang relevan dengan bidang PAUD mereka mempelajari berbagai ilmu pendidikan yang relevan dengan bidang PAUD, sedangkan guru yang memiliki ijazah terakhir S1 yang tidak relevan dengan bidang PAUD tidak mempelajari hal-hal tersebut secara formal, tetapi melalui kehidupan sehari-hari atau secara nonformal.

Guru yang tidak profesional mampu mempengaruhi adanya praktekpraktek pembelajaran yang berdampak negatif pada anak. Hal ini selaras dengan pernyataan Direktur Jenderal Pendidikan Anak Usia Dini, Nonformal 
dan Informal, Hamid (2011), yang menyatakan bahwa:

Kondisi pendidikan PAUD saat ini orientasinya lebih kepada model baca tulis dan berhitung. Padahal seharusnya, model membaca, menulis, dan berhitung (calistung) baru diajarkan pada level pendidikan dasar. Kondisi tersebut juga didukung dengan fakta bahwa sebanyak 3.298.428 atau 40,5 persen anak usia 5-6 tahun telah menjalani pendidikan di level sekolah dasar.

Menurut data dari Dinas Pendidikan Kabupaten Bogor saat ini PAUD sudah mulai banyak tersebar di Kecamatan Cibinong Kab. Bogor. Pada tahun 2016/2017 jumlah PAUD di Cibinong berjumlah 133, sedangkan tutor berjumlah 274, dan warga belajar nya berjumlah 4.430. Namun, seperti yang kita ketahui, masih banyak penerimaan guru yang bukan berlatar belakang pendidikan keguruan, khususnya PGPAUD. Hal ini masih menjadi pembicaraan, apakah kinerja guru akan sesuai dengan kualifikasi akademiknya atau tidak. Terlepas dari latar belakang pendidikan tersebut, seorang guru memang sudah seharusnya memiliki keinginan untuk terus belajar dan mencoba hal-hal baru.

$\begin{array}{lcr}\quad \text { Kasubdit } & \text { P2TK } & \text { PAUDNI, } \\ \text { Direktorat } & \text { Pembinaan } & \text { PAUD, } \\ \text { Kementrian } & \text { Pendidikan } & \text { dan }\end{array}$

Kebudayaan, Masyur, mengungkapkan bahwa "Khusus untuk guru TK/PAUD berjumlah sekitar 252 ribu. Dari jumlah itu baru sekitar 60 ribu yang terdaftar dan dari data yang ada juga bisa dihitung baru sekitar 10 persen yang benar-benar memenuhi kualifikasi” .
Penelitian yang dilakukan oleh Fitriya, (2014) menunjukkan bahwa latar belakang pendidikan guru PAUD berpengaruh terhadap kualitas kegiatan belajar mengajar (KBM) di kelas. Guru yang berlatar belakang pendidikan PGPAUD memiliki kinerja yang lebih baik daripada yang berlatar belakang non PGPAUD. Karena guru yang berlatar belakang S1 PGPAUD mempelajari teori-teori PAUD yang menjadi dasar bagi mereka dalam pelaksanaan KBM di kelas. Latar belakang pendidikan yang lebih tinggi juga mempengaruhi bagaimana seorang guru mampu melakukan KBM yang berkualitas. Terbukti dari tingkat pendidikan guru DII PGTK memiliki skor yang lebih kecil daripada guru yang menempuh pendidikan S1 PGPAUD dalam KBM di kelas.

Hasil penelitian yang dilakukan oleh Hasanah (2014) menyatakan bahwa, profil guru PAUD tentang kompetensi profesional mengajar ditinjau dari latar kualifikasi akademik di Kec. Nyalindung Kab. Sukabumi rata-rata berada pada kategori sedang, sedangkan kualifikasi akademiknya masih banyak yang belum sesuai dengan yang disyaratkan oleh pemerintah. Berdasarkan hasil penelitian tersebut dapat diasumsikan guru PAUD Kec. Nyalindung Kab. Sukabumi masih memiliki pengetahuan yang kurang maksimal tentang cara mengajar di PAUD yang baik dan masih perlu adanya upaya peningkatan kemampuan bagi guru PAUD Kec. Nyalindung Kab. Sukabumi.

Berdasarkan latar belakang masalah yang telah dikemukakan di atas penelitian ini dapat dirumuskan dalam pertanyaan penelitian sebagai berikut: 
1. Seperti apa profil kompetensi profesional guru TK di Kecamatan Cibinong Kabupaten Bogor ditinjau dari kualifikasi akademik?

2. Seperti apa profil kualifikasi akademik guru TK di Kecamatan Cibinong Kabupaten Bogor?

3. Adakah perbedaan profil kompetensi profesional guru TK di Kecamatan Cibinong Kabupaten Bogor ditinjau dari kualifikasi akademik?

Tujuan umum dalam penelitian ini adalah sebagai berikut:

1. Untuk mengetahui profil kompetensi profesional guru TK di Kecamatan Cibinong Kabupaten Bogor ditinjau dari kualifikasi akademik.

2. Untuk mengetahui profil kualifikasi akademik guru TK di Kecamatan Cibinong Kabupaten Bogor.

3. Untuk mengetahui perbedaan profil kompetensi profesional guru TK di Kecamatan Cibinong Kabupaten Bogor ditinjau dari kualifikasi akademik.

4. Untuk menguji hipotesis.

\section{METODE}

Metode penelitian yang digunakan dalam penelitian ini adalah metode Ex Post Facto.

Sukardi (2003, hlm. 174) mengatakan bahwa penelitian Ex Post Facto adalah penelitian di mana rangkaian-rangkaian variabel bebas telah terjadi, ketika peneliti mulai melakukan pengamatan terhadap variabel terikat.

Dapat disimpulkan bahwa penelitian Ex Post Facto tidak memberikan treatment atau perlakuan selama penelitian berlangsung, dengan tujuan untuk mengetahui hubungan sebab-akibat antar variabel.

Populasi dalam penelitian ini adalah seluruh guru TK di Kecamatan Cibinong Kabupaten Bogor yang memiliki kualifikasi akademik S1 yang relevan dengan bidang PAUD dan S1 yang tidak relevan dengan bidang PAUD. Sedangkan guru di Kecamatan Cibinong Kabupaten Bogor

Adapun Teknik sampling yang digunakan dalam penelitian ini adalah teknik sampling jenuh. Seperti yang dikatakan oleh Sugiyono (2001, hlm. 61) sampling jenuh adalah teknik penentuan sampel bila semua anggota populasi dijadikan sampel. Pada umumnya, teknik sampling ini digunakan apabila populasi yang dimiliki berjumlah di bawah 100 .

Teknik pengumpulan dalam penelitian ini adalah menggunakan tes formatif berbentuk pilihan ganda. Tes formatif berbentuk pilihan ganda adalah tes bersifat mengukur yang berisi pertanyaan atau pernyataan yang alternatif jawabannya memiliki standar jawaban tertentu, benar-salah ataupun skala jawaban. (Sukmadinata, 2011, hlm 230).

HASIL DAN PEMBAHASAN

A. HASIL

1. Profil Kompetensi Profesional Guru Taman Kanak Kanak di Kecamatan Cibinong Kabupaten Bogor ditinjau dari Kualifikasi Akademiknya 
Profil Kompetensi Profesional Guru TK yang memiliki ijazah

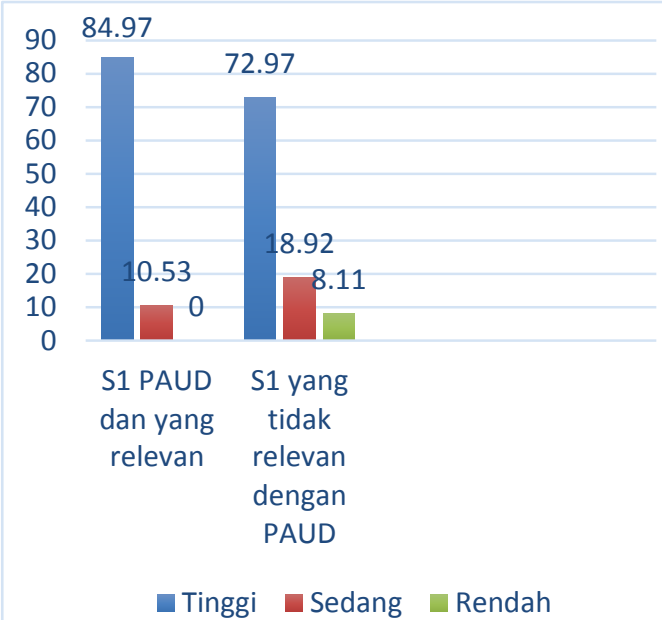

terakhir S1 yang relevan dengan bidang PAUD dan S1 yang tidak relevan dengan bidang PAUD dapat dipaparkan pada grafik berikut

Grafik di atas menunjukkan bahwa profil kompetensi profesional guru TK di Kecamatan Cibinong Kabupaten Bogor dengan jumlah persentase guru yang memiliki ijazah terakhir S1 yang relevan dengan bidang PAUD paling banyak adalah $84,97 \%$ yaitu berada pada kategori tinggi dan paling sedikit adalah 10,53 \% yaitu berada pada kategori sedang. Sedangkan profil kompetensi profesional guru yang memiliki ijazah terakhir S1 yang tidak relevan dengan bidang PAUD memiliki persentase paling banyak $72,97 \%$ yaitu berada pada kategori tinggi, kemudian paling sedikit adalah $8,11 \%$ yaitu berada pada kategori rendah, dan 18,92 $\%$ pada kategori sedang.

a. Profil Kompetensi Profesional Guru berdasarkan aspek mengembangkan materi, struktur, dan konsep bidang keilmuan yang mendukung serta sejalan dengan kebutuhan dan tahapan perkembangan anak usia dini.
Presentase Profil kompetensi profesional guru berdasarkan aspek mengembangkan materi, struktur, dan konsep bidang keilmuan yang mendukung serta sejalan dengan kebutuhan dan tahapan perkembangan anak usia dini.

dapat diuraikan pada grafik berikut.

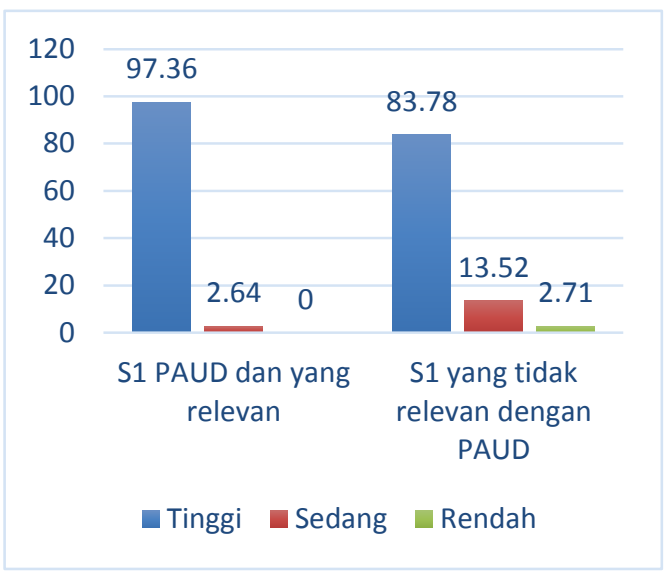

Berdasarkan pada grafik 4.2 di atas diperoleh bahwa persentase tertinggi profil kompetensi profesional berdasarkan aspek mengembangkan materi, struktur, dan konsep bidang keilmuan yang mendukung serta sejalan dengan kebutuhan dan tahapan perkembangan anak usia dini pada guru yang memiliki ijazah $\mathrm{S} 1$ yang relevan dengan bidang PAUD mencapai 97,36 $\%$ dalam kategori tinggi dan persentase paling rendah $2,64 \%$ dalam kategori sedang dan tidak ada dalam kategori rendah. Sedangkan kelompok guru yang memiliki ijazah S1 yang tidak relevan dengan bidang PAUD memiliki persentase paling tinggi $83,78 \%$ dalam kategori tinggi, dan persentase paling rendah 2,71\% dalam kategori rendah

b. Profil kompetensi profesional guru berdasarkan aspek merancang berbagai kegiatan pengembangan secara kreatif sesuai dengan tahapan perkembangan anak usia dini. 
Profil kompetensi profesional guru berdasarkan aspek merancang berbagai kegiatan pengembangan secara kreatif sesuai dengan tahapan perkembangan anak usia dini dapat diuraikan dalam grafik berikut.

Berdasarkan pada grafik $4.3 \mathrm{di}$ atas diperoleh bahwa persentase tertinggi profil kompetensi profesional berdasarkan aspek merancang berbagai kegiatan pengembangan secara kreatif sesuai dengan tahapan perkembangan anak usia dini pada guru yang memiliki ijazah S1 yang relevan dengan bidang PAUD mencapai 71,05 \% dalam kategori sedang dan persentase paling rendah 5,27 \% dalam kategori rendah. Sedangkan kelompok guru yang memiliki ijazah S1 yang tidak relevan dengan bidang PAUD memiliki persentase paling tinggi $62,17 \%$ dalam kategori sedang, dan persentase paling rendah $2,71 \%$ dalam kategori rendah.

c. Profil kompetensi profesional guru berdasarkan aspek mengembangkan keprofesionalan secara berkelanjutan dengan melakukan tindakan reflektif.

Profil kompetensi profesional guru berdasarkan aspek mengembangkan keprofesionalan secara berkelanjutan dengan melakukan tindakan reflektif dapat diuraikan dalam grafik berikut.

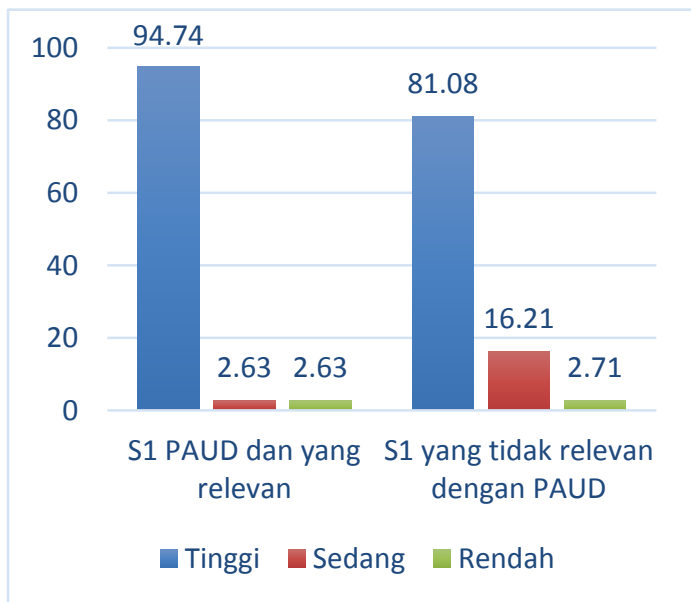

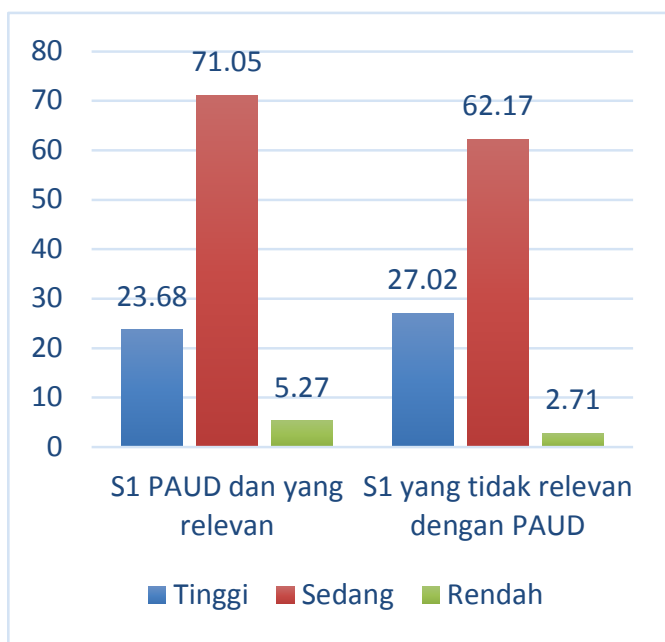

2. Profil Kualifikasi Akademik Guru TK di Kecamatan Cibinong Kabupaten Bogor

Profil Kualifikasi Akademik Guru TK di Kecamatan Cibinong Kabupaten Bogor dapat diuraikan dalam grafik berikut.

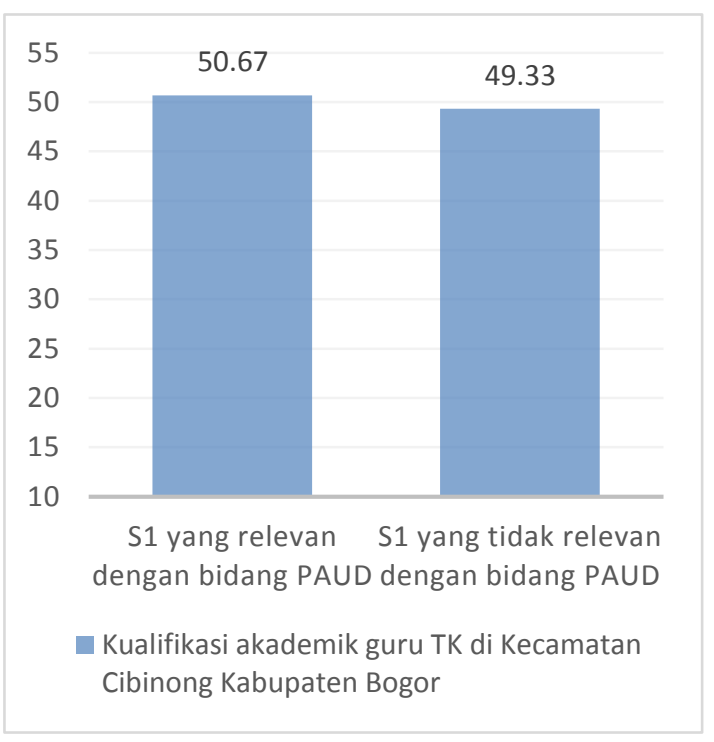

Dari grafik di atas dapat disimpulkan bahwa kualifikasi akademik guru TK di Kecamatan Cibinong Kabupaten Bogor memiliki penyebaran guru yang hampir seimbang antara guru yang memiliki ijazah terakhir S1 yang relevan dengan bidang PAUD dan S1 yang tidak relevan 
dengan bidang PAUD, yaitu dengan persentase 50,67\%:49,33\%.

3. Perbedaan Kompetensi Profesional Guru TK yang Memiliki Ijazah Terakhir S1 yang relevan dengan bidang PAUD dan S1 yang tidak relevan dengan bidang PAUD di Kecamatan Cibinong

Berdasarkan hasil penghitungan uji $\mathrm{F}$ menggunakan program IBM SPSS 24 didapatkan nilai $\mathrm{F}$ sebesar 2,379 dengan tingkat signifikasni 0,021. Karena tingkat signifikan yang dihasilkan kurang dari 0,05 , maka $\mathrm{H}_{\mathrm{o}}$ ditolak dan $\mathrm{H}_{\mathrm{a}}$ diterima, hal ini dapat diartikan bahwa terdapat perbedaan kompetensi profesional antara guru yang memiliki ijazah terakhir S1 yang relevan dengan bidang PAUD dan S1 yang tidak relevan dengan PAUD, oleh karena itu pengambilan t-Test for equality means menggunakan data equal variance not assumed.

Berdasarkan hasil perhitungan t-Test menggunakan program IBM SPSS 24 didapatkan nilai t-hitung sebesar 2,379 dengan tingkat signifikansi sebesar 0,021. Karena tingkat signifikansi kurang dari 0,05, maka maka $\mathrm{H}_{\mathrm{o}}$ ditolak dan $\mathrm{H}_{\mathrm{a}}$ diterima, hal ini dapat diartikan bahwa terdapat perbedaan kompetensi profesional antara guru yang memiliki ijazah terakhir S1 yang relevan dengan bidang PAUD dan $\mathrm{S} 1$ yang tidak relevan dengan PAUD.

Perbedaan Kompetensi Profesional Guru TK yang Memiliki Ijazah Terakhir S1 yang relevan dengan bidang PAUD dan S1 yang tidak relevan dengan bidang PAUD di Kecamatan Cibinong dapat diuraikan dalam grafik berikut.

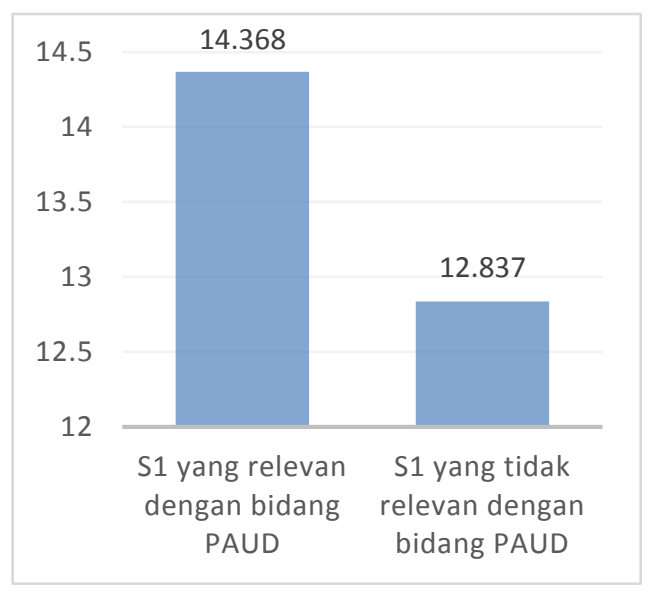

PEMBAHASAN

1. Profil Pengelolaan Lingkungan Belajar Lembaga Pendidikan Anak Usia Dini yang Berada di Kawasan Rawan Bencana berdasarkan Dimensi Prinsip Pengelolaan Lingkungan Belajar Indoor.

Hasil penelitian menunjukkan bahwa terdapat $84,97 \%$ guru TK yang memiliki ijazah terakhir S1 yang relevan dengan bidang PAUD yang berada pada kategori tinggi dalam profil nya mengenai kompetensi profesional. Hal ini dapat diartikan bahwa profil guru TK di Kecamatan Cibinong mengenai kompetensi profesional sudah baik, pengetahuan ini sangat berguna bagi guru untuk mencapai tujuan yang hendak dicapai dan untuk meningkatkan profesionalitasnya. Begitu pula dengan guru TK yang memiliki ijazah terakhir S1 yang tidak relevan dengan bidang PAUD, kelompok guru ini memiliki persentase yang sedikit lebih rendah dari guru TK yang memiliki ijazah terakhir S1 yang relevan dengan bidang PAUD, yaitu berjumlah $72,97 \%$ dan termasuk dalam kategori tinggi. Dapat diartikan bahwa 
profil kompetensi profesional pada kelompok guru ini juga sudah baik. Namun, hal ini juga dapat menjadi salah satu faktor pendukung dalam penelitian ini bahwa persentase profil kompetensi profesional guru yang lebih tinggi dimiliki oleh guru TK yang memiliki ijazah terakhir S1 yang relevan dengan bidang PAUD daripada guru TK yang memiliki ijazah terakhir S1 yang tidak relevan dengan bidang PAUD. Dapat dilihat pada kategori rendah, kelompok guru yang memiliki ijazah terakhir S1 yang relevan dengan bidang PAUD memiliki jumlah persentase $0 \%$ atau tidak ada guru yang masuk dalam kategori rendah, sedangkan pada kelompok guru yang memiliki ijazah terakhir S1 yang tidak relevan dengan bidang PAUD memiliki jumlah persentase $8,11 \%$. Namun, di antara kedua kelompok guru ini tidak terdapat perbedaan jumlah persentase yang cukup banyak, artinya profil kompetensi profesional di antara kedua kelompok guru ini tidak jauh berbeda. Kualifikasi akademik guru TK merupakan salah satu komponen yang sangat penting dalam sistem pendidikan. Guru memiliki peran dan tanggung jawab tersendiri dalam mengembangkan kemampuan anak dengan dasar-dasar ilmu yang dimilikinya. Oleh karena itu, seorang guru TK harus memiliki pengetahuan dasar-dasar keilmuan mengenai keguruan terutama dalam bidang anak usia dini. Semakin baik profil seorang guru, maka semakin baik pula kualitas pengajaran dan pelayanan yang guru berikan terhadap anak. Sejalan dengan ketentuan kualifikasi akademik yang sudah ditetapkan dalam Permendikbud No. 137 Tahun 2014 bahwa seorang guru PAUD harus memiliki kualifikasi akademik minimal D-IV atau S1 dalam bidang PAUD atau yang relevan, karena mereka telah memiliki dasar-dasar keilmuan tentang keguruan dan juga pendidikan anak usia dini. Hasil penelitian ini mendukung hasil penelitian dari Fitriya (2014), dimana hasil penelitian menunjukkan bahwa latar belakang pendidikan guru PAUD berpengaruh terhadap kulitas kegiatan belajar mengajar (KBM) di kelas. Apabila kualifikasi akademik seorang guru lebih baik dan sesuai maka akan semakin mudah untuk meningkatkan profesionalisme guru tersebut. Undang Undang Guru dan Dosen Nomor 14 Tahun 2005 pasal guru dikatakan sebagai tenaga profesional yang memiliki arti bahwa pekerjaan guru hanya dapat dilakukan oleh seorang yang memiliki kualifikasi akademik, kompetensi, dan sertifikat pendidik sesuai dengan persyaratan untuk setiap jenis dan jenjang pendidikan tertentu. Selain kualifikasi akademik, faktor lain yang mendukung yaitu pengalaman mengajar dan juga sertifikasi guru.

\section{a. Profil Guru TK pada Aspek Mengembangkan Materi, Struktur, dan Konsep Bidang Keilmuan yang Mendukung Serta Sejalan dengan Kebutuhan dan Tahapan Perkembangan Anak Usia Dini ditinjau dari Kualifikasi Akademiknya.}

Berdasarkan hasil penelitian profil kompetensi profesional pada aspek mengembangkan materi, struktur, dan konsep bidang keilmuan yang mendukung serta sejalan dengan kebutuhan dan tahapan perkembangan anak usia dini yang meliputi menelaah konsep dasar keilmuan yang sesuai dengan kebutuhan, tahapan perkembangan dan psikomotorik anak dan mengorganisasikan konsep dasar 
keilmuan sebagai alat, aktivitas, dan konten dalam pengembangan anak usia dini, pada umumnya pengetahuan ini dimiliki oleh guru TK di Kecamatan Cibinong yang memiliki ijazah terakhir S1, hanya saja profil yang membedakannya. Pada kelompok guru yang memiliki ijazah terakhir S1 profil mereka dalam menelaah konsep ilmu matematika, sains, bahasa, studi sosial, seni, dan agama serta dalam mengorganisasikan konsep dasar keilmuan tersebut dalam perkembangan anak sudah baik, terlihat jika dalam bentuk persentase berjumlah 97,36\% yang artinya hampir seluruh guru yang memiliki ijazah terakhir S1 yang relevan dengan bidang PAUD memiliki profil yang termasuk dalam kategori tinggi, sedangkan 2,64 \% sisanya termasuk dalam kategori sedang dan tidak ada yang memiliki kategori rendah. Sejalan dengan pendapat Surya (dalam Kusnandar, 2007, hlm. 47) bahwa guru yang profesional akan tercermin dalam pelaksanaan pengabdian tugas-tugas yang ditandai dengan keahlian baik dalam materi maupun metode. Selain itu juga ditunjukkan melalui tanggung jawabnya dalam melaksanakan seluruh pengabdiannya.

Sedangkan profil guru TK berdasarkan aspek mengembangkan materi, struktur, dan konsep bidang keilmuan yang mendukung serta sejalan dengan kebutuhan dan tahapan perkembangan anak usia dini pada kelompok guru yang memiliki ijazah terakhir S1 yang tidak relevan dengan bidang PAUD tidak memiliki perbedaan yang jauh dengan kelompok guru yang memiliki ijazah terakhir S1 yang relevan dengan bidang PAUD. Hal ini dapat dilihat dari jumlah persentase dalam kategori tinggi nya mencapai $83,78 \%$, dapat diartikan bahwa profilnya sudah baik. Sebagian besar kelompok guru ini sudah mengetahui bagaimana cara menelaah dan mengorganisasikan konsep-konsep dasar keilmuan yang mereka miliki dari pendidikan mereka sebelumnya untuk kemudian disesuaikan dengan aktivitas dan kegiatan yang dibutuhkan dalam mengembangkan anak usia dini. Hal ini juga bisa dipengaruhi oleh pengalaman mengajar yang sudah cukup lama sehingga mereka mempelajari teori-teori ke-paud-an dengan cara terjun langsung ke lapangan tanpa mendapatkan pendidikan guru anak usia dini sebelumnya. Selain itu, sertifikasi dan PPG juga menjadi pertimbangan mengapa kelompok guru yang memiliki ijazah terakhir S1 yang tidak relevan dengan bidang PAUD memiliki profil kompetensi profesional yang tinggi dalam aspek ini. Jika diibaratkan, sertifikasi atau PPG merupakan salah satu sarana mereka untuk belajar lebih banyak lagi mengenai pendidikan anak usia dini. Hal ini dapat diperkuat dengan pendapat Shoimin (2013, hlm. 81) sertifikasi guru adalah proses pemberian sertifikasi pendidik kepada guru, sertifikat pendidikan diberikan kepada guru yang telah memenuhi standar profesional guru. Guru profesional merupakan syarat mutlak untuk menciptakan sistem dan praktik pendidikan yang berkualitas.

\section{b. Profil Guru TK pada Aspek Merancang Berbagai Kegiatan Pengembangan Secara Kreatif Sesuai dengan Tahapan Perkembangan Anak Usia Dini ditinjau dari Kualifikasi Akademiknya.}

Berdasarkan hasil penelitian mengenai profil guru TK pada aspek merancang berbagai kegiatan 
pengembangan secara kreatif sesuai dengan tahapan perkembangan anak usia dini yang meliputi merumuskan tujuan dan menganalisis perkembangan anak usia dini dalam setiap bidang pengembangan, serta memilih materi berbagai kegiatan pengembangan dan mengorganisasikan kegiatan pengembangan secara kreatif sesuai dengan tingkat perkembangan anak usia dini, kelompok guru yang memiliki ijazah terakhir S1 yang relevan dengan bidang PAUD memiliki jumlah persentase tinggi yang dapat terbilang sedikit, jauh berbeda dengan aspek sub variabel yang pertama. Pada aspek ini, kelompok guru tersebut memiliki jumlah persentase tertinggi pada kategori sedang yaitu berjumlah $71,05 \%$, sedangkan pada kategori tinggi berjumlah 23,68 \% atau hanya sembilan orang yang memiliki profil tinggi dalam aspek merancang kegiatan pengembangan secara kreatif sesuai dengan tahapan perkembangan anak. Hal ini bisa saja disebabkan oleh beberapa faktor. Menurut DarlingHammond dan Goodwin (1993, hlm 25) ada beberapa karakteristik dalam pekerjaan profesional salah satunya adalah pekerjaan dilandasi berdasarkan ilmu yang terkait yang disebut sebagai "codified of knowledge", dari karakteristik tersebut dapat diartikan bahwa guru harus memiliki pemahaman yang mendalam tentang bagaimana karakteristik peserta didik, termasuk dalam bidang kurikulum pendidikan peserta didik, pengelolaan pembelajaran yang mencakup perencanaan, pelaksanaan, dan penilaian proses pembelajaran serta pengembangan kemampuan profesional secara berkelanjutan. Hasil penelitian pada aspek ini mendukung hasil penelitian Prianggita (2008) yang menyebutkan bahwa faktor penghambat penerapan pembelajaran yang sesuai dengan tahapan perkembangan anak salah satunya adalah tuntutan orang tua yang memiliki ambisi pada anak untuk bisa membaca dan berhitung pada usia yang belum seharusnya, faktor lain adalah pemahaman guru mengenai pengelolaan pembelajaran di kelas, dan kurangnya pelayanan bimbingan kepada orang tua mengenai tujuan-tujuan sekolah.

Hasil penelitian profil kompetensi profesional guru TK berdasarkan aspek merancang berbagai kegiatan pengembangan secara kreatif sesuai dengan tahapan perkembangan anak usia dini pada kelompok guru yang memiliki ijazah terakhir $\mathrm{S} 1$ yang tidak relevan dengan bidang PAUD menunjukkan hal yang tidak jauh berbeda dengan kelompok guru yang memiliki ijazah terakhir S1 yang relevan dengan bidang PAUD. Dapat dilihat dari persentase paling tinggi dalam aspek ini adalah $62,17 \%$ dalam kategori sedang, sedangkan dalam kategori tinggi hanya berjumlah $27,02 \%$. Namun pada kategori kelompok guru yang memiliki ijazah terakhir S1 yang tidak relevan mengungguli beberapa persen dari kelompok guru yang memiliki ijazah terakhir S1 yang relevan dengan bidang PAUD. Faktor penyebab dari hal ini kurang lebih sama dengan kelompok guru yang sebelumnya.

\section{c. Profil Guru TK pada Aspek Mengembangkan Keprofesionalan Secara Berkelanjutan Dengan Melakukan Tindakan Reflektif ditinjau dari Kualifikasi Akademiknya.}

Hasil penelitian menunjukkan bahwa profil guru TK berdasarkan aspek mengembangkan keprofesionalan secara berkelanjutan dengan melakukan tindakan reflektif ditinjau dari kualifikasi 
akademik pada kelompok guru TK yang memiliki ijazah terakhir S1 yang relevan dengan bidang PAUD menunjukkan persentase pada kategori tinggi berjumlah $94,74 \%$, dan $2,63 \%$ pada dua kategori yaitu kategori sedang dan kategori rendah. Hal ini menunjukkan bahwa profil kelompok guru pada aspek ini sudah baik, karena sebagian besar dari kelompok guru ini sudah termasuk dalam kategori tinggi. Kelompok guru yang memiliki ijazah terakhir S1 yang relevan dengan bidang PAUD sudah memiliki pengetahuan mengenani bagaimana cara melakukan refleksi terhdapa kinerja diri sendiri dan pengetahuan mengenai bagaimana memanfaatkan hasil refleksi tersebut dalam rangka meningkatkan keprofesionalan mereka dalam mengajar. Menjadi guru yang reflektif, menurut Harmer (2007, hlm 410) adalah terus berkaca pada apa yang sudah dilakukan. Terus berfikir apa yang kita lakukan dan mengapa. Hal serupa juga dinyatakan oleh Richards \& Lockhart (1996) bahwa cara atau pendekatan yang dilakukan oleh guru dimana ia mengeksplorasi apa yang dilakukan dan alasan mengapa melakukannya merupakan bagian dari tindakan reflektif dalam pengajaran. Tindaka reflektif diperlukan bagi seluruh guru, terutama guru yang memiliki pengalaman mengajar yang cukup lama. Tindakan reflektif bertujuan untuk meningkatkan keprofesionalan seorang guru dengan cara mempelajari dari kesalahan-kesalahan sebelumnya yang telah dilakukan atau teman sejawat lakukan untuk kemudian menjadi pelajaran di masa yang akan datang, dan juga melakukan tindakan-tindakan yang mampu meningkatkan pengetahuan guru demi kelancaran pendidikan. Hal ini selaras dengan pernyataan Setiasih (2008, hlm. 21) bahwa:
Pengembangan profesi tenaga pendidik PAUD secara garis besar dapat dilakukan melalui dua macam jalur, yaitu jalur individual, dan jalur kelembagaan. Jalur individual adalah usaha pengembangan profesi yang dilakukan oleh setiap orang baik secara langsung maupun tidak langsung melaksanakan pekerjaan dan tugas sebagai pendidik (guru, tutor, fasilitator, atau sebutan lainnya). Sedangkan jalur kelembagaan adalah upaya pengembangan profesi pendidik PAUD yang diselenggarakan melalui lembaga pendidikan formal, non formla, dan organisasi profesi.

Hasil penelitian profil kelompok guru yang memiliki ijazah terakhir S1 yang tidak relevan dengan bidang PAUD berdasarkan aspek mengembangkan keprofesionalan secara berkelanjutan dengan melakukan tindakan reflektif memiliki jumlah persentase pada kategori tinggi yang tidak jauh berbeda dengan kelompok guru yang sebelumnya yaitu $81,08 \%$, sedangkan untuk kategori sedang berjumlah $16,21 \%$ dan 2,71\% untuk kategori paling rendah. Apabila persentase pada aspek ini dibandingkan dengan kelompok guru yang sebelumnya, maka profil kelompok guru tersebut sedikit lebih unggul daripada kelompok guru yang memiliki ijazah terakhir S1 yang tidak relevan dengan bidang PAUD, walaupun keduanya memiliki nilai yang sama-sama tinggi. Artinya kedua kelompok guru ini sudah menyadari bahwa tindakan reflektif tidak hanya dilakukan oleh guru yang baru memiliki pengalaman mengajar yang sedikit, tetapi para guru yang sudah memiliki pengalaman mengajar yang lama tetap harus melakukan tindakan reflektif, responden dari penelitian ini pun sebagian besar memiliki pengalaman mengajar yang sudah cukup lama. Karena menjadi guru harus siap untuk belajar 
sepanjang hayat. Sejalan dengan Undang Undang Nomor 20 Tahun 2003 tentang Sistem Pendidikan Nasional Pasal 4 Ayat (3) menyebutkan bahwa "Pendidikan diselenggarakan sebagai suatu proses pembudayaan dan pemberdayaan peserta didik yang berlangsung sepanjang hayat". Artinya dalam kehidupan seseorang harus terus belajar, termasuk seorang guru.

\section{Profil Kualifikasi Akademik Guru TK di Kecamatan Cibinong Kabupaten Bogor}

Berdasarkan data yang didapatkan dari UPT PAUD dan Nonformal Kecamatan Cibinong Kabupaten Bogor bahwa TK di Kecamatan Cibinong Kabupaten Bogor berjumlah 37 TK. Menurut Permendikbud No. 37 Tahun 2014 tentang Standar Kualifikasi Akademik dan Kompetensi Guru mengatakan bahwa "Guru PAUD/TK/RA harus memiliki kualifikasi akademik pendidikan minimum diploma empat (DIV) atau sarjana (S1) dalam bidang pendidikan anak usia dini atau psikologi yang diperoleh melalui program studi yang terakreditasi. Oleh karena itu, sudah seharusnya TK di Kecamatan Cibinong Kabupaten Bogor mematuhi apa yang sudah menjadi peraturan pemerintah.

Hasil penelitian menunjukkan bahwa kualifikasi akademik yang dimiliki guru TK di Kecamatan Cibinong Kabupaten Bogor sebagian besar sudah mengemban pendidikan S1. Sementara apabila dikelompokkan berdasarkan ijazah S1 maka akan menjadi dua kelompok yaitu guru yang memiliki ijazah terakhir S1 yang relevan dengan bidang PAUD dan S1 yang tidak relevan dengan bidang PAUD. Kelompok guru yang memiliki ijazah terakhir S1 yang relevan dengan bidang PAUD berjumlah 38 orang atau 50,67 \%. Sedangkan kelompok guru yang memiliki ijazah terakhir S1 yang tidak relevan dengan bidang PAUD berjumlah 37 orang dengan persentase 49,33 \%. Artinya, keberadaan kedua kelompok guru ini cukup seimbang. Namun, apabila kembali merujuk kepada Permendikbud No. 37 Tahun 2014 maka seharusnya seluruh guru TK di Kecamatan Cibinong Kabupaten Bogor harus memiliki kualifikasi akademik D-IV atau S1 yang relevan dengan bidang PAUD. Ada beberapa hal yang mungkin menjadi faktor penyebab dari adanya guru yang kualifikasi akademiknya tidak memenuhi peraturan pemerintah, diantaranya:

a. Faktor Eksternal

1) Faktor Ekonomi

Meneruskan pendidikan ke tingkat selanjutnya merupakan tindakan yang dipertimbangkan oleh guru, karena untuk mengemban pendidikan tersebut artinya guru harus mengeluarkan biaya lagi.

2) Faktor Lingkungan

Banyak orang-orang yang beranggapan bahwa menjadi seorang guru PAUD/TK merupakan hal yang mudah dan tidak membutuhkan pendidikan profesi guru sebelumnya.

b. Faktor Internal

1) Faktor Usia

Usia yang sudah tua juga dapat mempengaruhi guru untuk tidak melanjutkan studi nya ke pendidikan yang lebih lanjut, karena kesehatan yang semakin menurun dan waktu yang dimilikinya tidak banyak.

3. Perbedaan Profil Kompetensi Profesional Guru TK yang Memiliki Ijazah Terakhir S1 yang relevan dengan bidang PAUD dan S1 yang tidak relevan dengan bidang PAUD di Kecamatan Cibinong

Hasil penelitian menunjukkan bahwa terdapat perbedaan antara guru TK yang memiliki ijazah terakhir S1 yang relevan 
dengan bidang PAUD dan S1 yang tidak relevan dengan bidang PAUD. Hal ini dapat dilihat dari besarnya rata-rata yang dimiliki oleh masing-masing kelompok guru. Kelompok guru yang memiliki ijazah terakhir S1 yang relevan dengan bidang PAUD menggungguli dengan memperoleh rata-rata sebesar 14,368, sedangkan pada kelompok guru yang memiliki ijazah terakhir S1 yang tidak relevan dengan PAUD memperoleh ratarata sebesar 12,837, dari hasil ini sudah terlihat jelas bahwa kompetensi profesional pada kedua kelompok ini memiliki perbedaan, walaupun perbedaan tersebut tidak terlalu jauh. Letak perbedaan yang signifikan antara kedua kelompok guru tersebut terdapat pada aspek mengembangkan dasar keilmuan yang sesuai dengan kebutuhan dan tahapan perkembangan anak usia dini, pada guru S1 yang relevan dengan bidang PAUD tida terdapat guru yang berada pada kategori rendah, sedangkan pada guru S1 yang tidak relevan dengan bidang PAUD terdapat guru yang berada pada kategori rendah.

Menurut Sugiyono (dalam Pudyastuti, 2010, hlm. 3) kemampuan guru dapat dipengaruhi oleh beberapa faktor seperti potensi dasar dalam diri, latar belakang pendidikan, pendidikan ataupun pelatihan, dan pengalaman belajar. Tingkat pendidikan yang ditempuh oleh seorang guru merupakan usaha yang guru lakukan untuk memiliki kompetensi yang baik, sehingga guru sudah memiliki dasar-dasar ilmu pendidikan untuk selanjutnya diaplikasikan ketika mereka sudah memasuki lingkungan kerja. Sementara guru yang tidak mengemban pendidikan yang relevan dengan bidang PAUD tidak mendapatkan dasar-dasar ilmu pendidikan sebagai salah satu syarat untuk menjadi seorang guru, sehingga pada pengaplikasiannya di lingkungan kerja belum optimal. Salah satu cara meningkatkan kompetensi profesional tersebut supaya optimal adalah dengan mengikuti program pelatihan guru dari pemerintah, mengikuti program pelatihan yang bersifat nonformal, berdiskusi dengan sesame guru, membaca literasi tentang ilmu pendidikan, dan melakukan tindakan reflektif. Namun, ada beberapa hal yang mungkin menjadi faktor penyebab rendahnya profil kompetensi profesional seorang guru yaitu, iklim organisasi sekolah, supervisi, dan hubungan antar teman sejawat maupun dengan kepala sekolah, tetapi hal-hal tersebut tidak menjadi bahasan dalam penelitian ini.

\section{SIMPULAN DAN REKOMENDASI}

\section{SIMPULAN}

\section{A. Simpulan}

Berdasarkan penelitian yang dilakukan pada guru TK di Kecamatan Cibinong Kabupaten Bogor maka dapat diperoleh kesimpulan sebagai berikut:

1. Profil kompetensi profesional guru TK yang memiliki ijazah terakhir S1 yang relevan dengan PAUD sebagian besar berada pada kategori tinggi, dalam beberapa aspek kelompok guru ini tidak memiliki kategori rendah. Artinya kompetensi profesional guru sudah baik. Pada aspek merencanakan kegiatan yang sesuai dengan tahapan perkembangan anak usia dini kelompok guru ini sebagian besar berada pada kategori sedang, faktor yang dapat mempengaruhi hal tersebut salah satunya adalah tuntutan orang tua mengenai kegiatan pembelajaran kepada pihak sekolah sehingga sekolah merasa memiliki tanggung jawab untuk 
melayani orang tua murid dengan baik. Namun, secara umum kelompok guru yang memiliki ijazah terakhir S1 yang relevan dengan bidang PAUD sudah baik.

Sedangkan profil kompetensi profesional guru TK yang memiliki ijazah S1 yang tidak relevan dengan PAUD sebagian besar berada pada kategori tinggi juga, hanya saja persentase yang diperoleh lebih sedikit daripada kelompok guru yang memiliki ijazah terakhir S1 yang tidak relevan dengan bidang PAUD. Hal ini mungkin disebabkan oleh beberapa faktor, salah satunya adalah kualifikasi akademik yang dimiliki tidak relevan dengan bidang PAUD, sehingga dasar-dasar ilmu pendidikan yang dimiliki tidak sebaik kelompok guru yang sebelumnya. Namun, secara keseluruhan kompetensi profesional guru yang memiliki ijazah terakhir S1 yang tidak relevan dengan bidang PAUD sudah cukup baik.

2. Profil kualifikasi akademik guru TK di Kecamatan Cibinong Kabupaten Bogor memiliki jumlah guru S1 yang relevan dengan bidang PAUD dan S1 yang tidak relevan dengan bidang PAUD yang seimbang. Sebagian guru sudah memenuhi kualifikasi akademik sesuai dengan peraturan pemerintah dan sebagian lagi belum memenuhi kualifikasi yang sesuai dengan peraturan pemerintah.

3. Secara keseluruhan terdapat perbedaan profil kompetensi profesional dalam aspek mengembangkan dasar keilmuan, merancang kegiatan, dan melakukan tindakan reflektif pada guru TK yang memiliki ijazah terakhir S1 yang relevan dengan bidang PAUD dan S1 yang tidak relevan dengan bidang
PAUD di Kecamatan Cibinong Kabupaten Bogor.

\section{REKOMENDASI}

Berdasarkan kajian teoretis dari hasil penelitian ini, peneliti memberikan beberapa rekomendasi seperti berikut ini:

1. Bagi Guru

Sebagai salah satu upaya meningkatkan kompetensi profesional hendaknya guru melakukan beberapa hal yaitu:

a. Mengikuti pelatihan maupun kegiatan yang berhubungan dengan PAUD, mengingat bahwa teori dan praktek harus memiliki keseimbangan supaya tercipta lingkungan belajar yang optimal.

b. Meningkatkan kualifikasi akademik dengan melanjutkan pendidikan ke jenjang yang lebih tinggi sesuai dengan profesi yang dijalani sebagaimana yang telah ditetapkan dalam Permendikbud No. 37 Tahun 2014.

2. Bagi Kepala Sekolah

Demi memajukan pendidikan di Indonesia hendaknya kepala sekolah melakukan beberapa hal terhadap guru yaitu:

a. Memberikan pembinaan kepada guru yang dilaksanakan secara sistematis dan berkelanjutan, karena iklim organisasi di sekolah juga dapat mempengaruhi kompetensi profesional seorang guru.

b. Memberikan dukungan, motivasi, dan kesempatan kepada guru untuk terus belajar supaya guru memiliki semangat untuk meningkatkan keprofesionalannya 
3. Bagi Pemerintah

a. Dinas Pendidikan hendaknya memberikan banyak pelatihan dan kegiatan yang berhubungan dengan bidang PAUD sebagai upaya meningkatkan kompetensi profesional guru.

b. Pemerintah diharapkan kembali mempertegas bahwa untuk menjadi seorang guru diperlukan kualifikasi akademik yang sesuai dengan peraturan pemerintah, sehingga tidak ada lagi guru yang kualifikasi akademiknya tidak sesuai dengan bidang profesinya.

4. Bagi Peneliti Selanjutnya

a. Diharapkan peneliti selanjutnya mampu menambah bahasan lain dan tidak terbatas pada kualifikasi akademik saja, seperti iklim organisasi, supervisi, kepemimpinan kepala sekolah, dan lain sebagainya, sehingga akan diketahui faktor mana yang paling mempengaruhi kompetensi profesional guru.

b. Penelitian diharapkan mampu dikaji lebih mendalam dan tidak terbatas pada kompetensi profesional saja tetapi juga tiga kompetensi lainnya yaitu kompetensi kepribadian, kompetensi sosial, dan kompetensi pedagogik.

c. Peneliti selanjutnya diharapkan bisa mengeksplor hasil penelitian ini untuk kemudian diuji kembali dengan metode penelitian yang lebih kompleks, sehingga penelitian ini mampu berkembang dan menghasilkan pemikiran-pemikiran baru.

d. Tidak disarankan untuk menggunakan instrumen dalam penelitian ini, kecuali melakukan konstruksi ulang pada instrumen ini sesuai dengan tata cara konstruksi tes.

\section{DAFTAR PUSTAKA}

Danim, S. (2010). Profesionalisasi dan Etika Profesi Guru. Bandung: Alfabeta

Darling-Hammond, L., \& Goodwin, A. L. (1993). Progress toward profesionalism in teaching. In Gordon Cawellti (Editor). Challenges and achievements of American Education. Alexandria: Association for supervision and curriculum development

Disdik Kabupaten Bogor. (2017). Jumlah PAUD, tutor, dan warga belajar 2016/2017. (Online). Tersedia di: http://disdik.bogorkab.go.id/inde x.php/multisite/page/1784.

Diakses 25 April 2017.

Evans, L. (2008). Professionalism, professionality and the development of education professionals. British journal of educational studies, 56 (1). pp. 20-38.

Fitriya, S.I.A. (2014) Tingkat pendidikan guru TK terhadap kualitas kegiatan belajar mengajar di Kecamatan Tawangharjo Kabupaten Grobogan. Skripsi. Universitas Muhammadiyah Surakarta, Surakarta.

Hamid, M. Direktorat Pembinaan Anak Usia Dini. (2012). Petunjuk Teknis Penyelenggaraan Taman Kanak-kanak.

Direktorat 
Jenderal Pendidikan Anak Usia Dini, Nonformal, dan Informal. Kementerian Pendidikan dan Kebudayaan. Diambil kembali dari

http://paud.kemdikbud.go.id/wpcontent/uploads/2016/03/JuknisPenyelenggaraan-TK.pdf. [Diakses 20 Desember 2017]

Harmer, J. (2007). The Practice of English Language Teaching (4 ${ }^{\text {th }}$ ed.). Essex: Pearson Education Limited.

Hasanah, S.A. (2014). Tingkat Pengetahuan Guru Pendidikan Anak Usia Dini Tentang Kompetensi Profesional Mengajar Ditinjau dari Latar Belakang Kualifikasi Akademiknya. Skripsi. Universitas Pendidikan Indonesia, PGPAUD FIP, Bandung.

Peraturan Menteri Pendidikan dan Kebudayaan No. 137 Tahun 2014 tentang Standar Nasional PAUD

Peraturan Menteri Pendidikan Nasional RI no. 58 Tahun 2009 tentang Standar PAUD

Prianggita, V. (2008). Pengembangan Kurikulum Sesuai dengan Perkembangan Anak (DAP) dalam Pengelolaan Pembelajaran PAUD. Skripsi, Universitas Mathla'ul Anwar, Fakultas Keguruan dan Ilmu Pendidikan.

Pudyastuti, S. (2011). Hubungan antara Latar Belakang Pendidikan Guru, Pengalaman Mengajar dan Pembelajaran dengan
Prestasi Belajar Siswa SMA Negeri 1 Surakarta. Skripsi, Universitas Sebelas Maret Surakarta, Fakultas Keguruan dan Ilmu Pendidikan, Surakarta.

Richards, J.C., dan Lockhart, C. (1996). Reflective teaching in Second Language Classroom. Cambridge: Cambridge University Press.

Setiasih, O. (2008). Etika Profesi. [Online]. Tersedia di: http://file.upi.edu/Direktori/FIP/ JUR._PEDAGOGIK/196007071 $\underline{986012}$ OCIH_SETIASIH/Hand_Out_E tika_Profesi.pdf. Diakses 27 Desember 2017.

Sugiyono. (2001). Metode Penelitian Administrasi. Bandung: CV Alfabeta.

Sukardi. (2003). Metodologi Penelitian Pendidikan Kompetensi dan Praktiknya. Jakarta: Bumi Aksara.

Sukmadinata, N.S. (2015). Metode Penelitian Pendidikan. Bandung: Remaja Rosdakarya.

Undang-Undang Nomor 20 Tahun 2003 tentang Sistem Pendidikan Nasional

Undang-Undang Republik Indonesia No. 14 Tahun 2005 tentang Guru dan Dosen

Shoimin, Aris. 2013. 68 Model Pembelajaran Inovatif dalam Kurikulum 2013. Yogyakarta: Ar-ruzz Media. 